\title{
Determinant of Bank Risk with Bank Scale as Moderating Variable in ASEAN
}

\author{
Susy Muchtar ${ }^{1}$, Adler Haymans Manurung ${ }^{2}$, Farah Margaretha ${ }^{3}$ \\ 1,3Trisakti University, Jakarta, Indonesia \\ ${ }^{2}$ Bhayangkara Jaya University, Indonesia \\ Email: susy_muchtar@trisakti.ac.id
}

\begin{abstract}
This research examines the determinant of bank risk with Bank Scale as the moderating variable. The determinants of bank risk in the study are Capital Adequacy Ratio (CAR), NonPerforming Loan (NPL), Loan to Deposit Ratio (LDR), Market Power (MP), Exchange Rate (ER), Interest Rate (IR), and Technology Investment (TI). Standard Deviation (STD) and Value at Risk ( $\mathrm{VaR})$ are proxies of bank risk. The bank scale is based on Bank Umum Kelompok Usaha (BUKU Bank). The unit of research analysis are conventional banks listed on the Stock Exchange of ASEAN-4 countries namely Indonesia Malaysia, Philippines, and Thailand during the period of 2010 - 2019 with a total of 35 banks. Panel data regression is used to determine bank risk. The examination was conducted on banks in ASEAN-4 countries and Indonesia. The results found that banks in ASEAN-4 countries: CAR, MP, ER, IR, TI, and BB have significant negative effect on STD and LDR have significant negative effect on VaR, MP and TI have significant positive effect on VaR. For banks in Indonesia, ER positively affects STD, IR and IT negatively affect STD, NPL positively affects VaR, LDR and TI negatively affect VaR. BB has no effect on bank risk. The results of this study are expected to contribute in bank management to pay attention on bank-specific variables, especially technology investments and macroeconomic variables due to their enormous influence in increasing profitability and lowering risks.
\end{abstract}

Keywords: Bank Risk, Bank Scale, Capital Adequacy Ratio, Exchange Rate, Interest Rate, Loan to Deposit Ratio, Market Power, Non-Performing Loan, Technology Investment.

\section{A. INTRODUCTION}

Global finance crisis is caused by widespread failures and losses from financial institutions which is lack of capital. When this shortage is severe, it can significantly reduce the credit supply and consequently hit the real economy (Engle \& Ruan, 2019). Post-crisis Regulation has changed from keeping individual institutions healthy to the impact of systemic risks which correlated to financial sector failures in ASEAN Region (Meuleman \& Vennet, 2020). Trung (2021) examined the systemic risks of ASEAN-6 countries, namely Indonesia, Malaysia, Philippines, Singapore, Thailand, and Vietnam. The systemic risk of commercial banks in the region was measured by "SRISK" metric during the period from 2000 to 2018. The results of his research ranked the severity of systemic banking risk between ASEAN-6 countries. The increasing liberalization of capital markets has led to significant market integration and the entry of large foreign investments into the ASEAN region has made the market very sensitive to global market movements. Large foreign investment in the ASEAN Region requires an ASEAN interbank regulation to anticipate foreign exchange fluctuations that will increase the bank risk ( $\mathrm{Wu}, 2019)$. Saheruddin \& Soedarmono (2019) examined bank risk using co-integration analysis and measured risk based on 
residuals from Capital Assets Pricing Model (CAPM), exploring the dynamic correlation between bank and market stocks with the DCC-GARCH model (Engle, 2002). The results suggest that the market will react to the bank's increased risk.

Capital regulation presents a minimum Capital Adequacy Ratio which is an important consideration in analyzing bank risk-taking. Large Capital Adequacy Ratio (CAR) will raise bank stability by improving the bank's ability to absorb and bear risks (Hunjra, Hanif, Mehmood, \& Nguyen, 2020). Van Roy (2008) argues that CAR's strict policy encourages banks to compensate for losses with optimal risk-raising options. Ashraf, Zheng, Jiang, \& Qian (2020) conducted the research using a sample of international banks from 111 countries and found that a strict capital adequacy ratio that only meets the minimum requirements of $8 \%$ reduces bank's risk exposure. Nguyen, Gan, \& Li (2019) analyzed a sample of Asian banks and concluded that strict capital regulation increases the probability of bank default. Jacques \& Nigro (1997) found a negative relationship between CAR and the level of risk in U.S commercial banks.

Banking regulators in Europe are increasingly concerned about high NonPerforming Loans (NPLs) in the EU banking sector due to interdependence between bank financing and economic growth (European Commission, 2014). High NonPerforming Loans pose significant risk to financial stability in the European Union (Ozili, 2020). Non-Performing Loans that are high due to systemic financial institutions will be charged to the bank's profits and can erode the bank's capital so that the risk increases. Louzis, Vouldis, \& Metaxas (2012) in their research shows when economic growth raises, banks tend to distribute the credit to low-quality debtors to generate higher incomes because the risk of financial difficulties was usually low during the boom. When the recession occurred, NPL of banking was expected to increase due to the incapability of debtors to repay loans that ultimately increased risk. Study of Ghosh (2015) states that financial crisis is often characterized by large non-performing loans that will increase the bank risk.

Ebenezer, Islam, Yusoff, \& Rahman (2019) conducted a research on 63 commercial banks in ASEAN-5 countries during the period of 2009 - 2017, using panel data regression. The results found that Loan to Deposit Ratio (LDR) had negative effect on bank risk. Wilner (2000) states that bank's function is based on liquidity because it offers an efficient institutional mechanism of how financial resources are mobilized and channeled to be productive investments that lower bank risk. An empirical evidence found that the best performing banks were the ones that maintained the deposit account levels associated with their assets. Increasing depositors' funds will raise the growth of productive assets, especially the credit sector, which will increase bank revenues so that liquidity risk will be reduced (Menicucci \& Paolucci, 2016).

Harkati, Alhabshi, \& Kassim (2020) stated that high economic freedom leads to increased competition which causes concentration to decrease due to the increasing number of banks, so banks will seek to take advantage of investment opportunities, even with the high risk. Market power negatively affects bank risk. Economic freedom 
can cause function of the bank improperly, resulting in increased risk (Harkati et al., 2020). A more concentrated banking market can reduce the interbank competition so that it will lower risk (Rehman, Khan, Khan, \& Rahman, 2018).

Exchange rate volatility plays an important role in macroeconomic and financial development (Barguellil, Salha, \& Zmami, 2018). Economic theory suggests that exchange rate volatility alters the relative price of goods and services produced at home and abroad causing changes in production, inflation, and interest rates, thus affecting the value of exports and imports (Chi, 2018). Exchange rate volatility reduces financial inflows to developing countries when viewed from a financial development perspective (Jehan \& Azooba, 2017). Risk of exchange rate has a flexible influence on financial industry such as banks. Fluctuations in the value of stronger foreign exchange will benefit debtors of exporter, resulting in increased capability to repay loans - thus affecting the bank risk. Conversely, the strengthening of foreign exchange will be problematic for debtors of importer in repaying their loans so that default risk will increase the bank risk (Amat, Michalski, \& Stoltz, 2018).

Interest rate intrinsically determines the level of consumption that consequently affects economic growth and investment in a country. On the other hand, the interest rate is considered as the price of deposits or costs to be paid to depositors and besides as the income to be received from debtors. Sensitivity on interest rate fluctuation is a variation in market risk which becomes a threat to the bank financial stability so that it will increase the risk (Ebenezer et al., 2019). Mahmud (2020) stated there is a positive influence between interest rates on bank risk. Increasing interest rate will raise the burden of debtors in paying principal and interest installments, especially short-term loans, so that the risk of unpaid loans will increase. But in the long run, interest rate has negative effect on bank risk.

The Covid-19 Pandemic, which is considered as one of the global crises, has had a drastic impact on the global financial sector (Phan \& Narayan, 2020). Social distancing, quarantine, and national lockdown have affected all sectors and brought insurmountable social and economic consequences and had a huge impact on ASEAN banking as the majority of economic activities, either directly or indirectly, are conducted through the banking sector (Wojcik \& Ioannou, 2020). The state government announced various stimulus to reduce the activities of people that will cause the pressure of liquidity on the global banking system which will eventually create a liquidity crisis that leads to the increasing non-performing loans (Narayan, Phan, \& Liu, 2021).

Will Digital Financial Inclusion (DFI) provide stability for ASEAN bankings? The appropriate DFI is necessary for smooth operations so that the public can conduct business and household transaction without fear of being exposed to virus (Wojcik \& Ioannou, 2020). The application of efficient technology is very important for the banking industry to maintain stability in order to conduct cashless financial operations (Banna \& Alam, 2021). Research shows that easily accessible financial services help banks to achieve stability, increase revenue, and reduce costs, be faster and more efficient, save time, and be cheaper (Ahamed \& Mallick, 2019). The trend of 
opening bank accounts in ASEAN countries through online platforms has been seen as a boost, so proper Digital Banking (DB) operations are expected to be a viable solution to address the current crisis, as it can be seen in what happened to the 2008 global financial crisis (Ahamed \& Mallick, 2019). Banks need to increase the investment in DB to improve their performance, so that risks can be reduced. Banna \& Alam (2021) stated that technology investment has negative effect on bank risk. The larger bank scale, the higher bank investment in technology because larger banks are more likely to be invested by investors.

Based on the explanation above, this study focuses on the risks faced by ASEAN bankings as most of the financing in the ASEAN region comes from bankings. Bank risk is an interesting topic to be examined, especially in the ASEAN-4 Region, namely Indonesia, Malaysia, Philippines, and Thailand. It has become one of the most dynamic regions with rapid economic growth and increased financial integration, making it highly sensitive to global market movements that lead to the influence of macroeconomic variables on the health of banks. The research was conducted during 2010 - 2019 using panel data regression to examine the determinants of bank risk using proxies of Total Risk (Standard Deviation) and Value at Risk moderated by bank scale. In this study, bank risk was influenced by bank-specific variables, such as Capital Adequacy Ratio, Non-Performing Loan, Loan to Deposit Ratio, Market Power, and Technology Investment, also by macroeconomic variables, such as Exchange Rate and Interest Rate.

\section{B. LITERATURE REVIEW}

Bank is a financial institution that collects funds from the public, both from companies and individuals, in the form of saving, current accounts, deposits and distributing them back to the public, namely companies and individuals, in the form of credit. Bank transforms the value, time, risk, and liquidity of funds received and distributed to the public. Bank must be capable to adjust the amount of funds received, the length of the deposit period with the amount of credit given, the length of the credit period, and the rate of return to be received for the credit distributed to the debtor as to cover the costs of depositors and refund depositors whenever the withdrawal is made (Manurung, Hutahayan, Deniswara, \& Kartika, 2020).

Risk becomes an important issue for banks. The bank risk consists of incapability to return the depositor's fund, withdrawals due to information that banks are experiencing liquidity crises or systemic effects from Too Big to Fail and debtors who are unable to repay loans provided due to the internal company problems or as a result of macroeconomic conditions, will affect the bank's ability refund depositors. The greater risk of bank's productive assets, the greater allowance for impairment losses, thus eroding bank's profitability and capital. Manurung, Kartono, Tjahjana, Tjiptadi \& Saputra (2021) formulated the bank capital mathematically as follows: 


$$
\begin{aligned}
& E_{1}=E_{0}+\pi_{1} \\
& E_{2}=E_{1}+\pi_{2}=E_{0}+\left\{\pi_{1}+\pi_{2}\right\} \\
& E_{n}=E_{0}+\left\{\pi_{1}+\pi_{2}+\cdots+\pi_{n}\right\}
\end{aligned}
$$

$E_{0}$ is the initial capital paid by the shareholders to the company. When the company is established with $t=0$, then the bank gets a profit $\left(\pi_{1}\right)$ (a loss can also occur) in the first year, so that the capital becomes $E_{1}$. When bank operates in the second year, the capital at the end of the second year increases by the profit earned $\left(\pi_{2}\right)$ so that the total capital becomes $E_{2}$. The Bank may increase its capital due to profits $\left\{\pi_{1}+\pi_{2}+\cdots+\pi_{n}\right\}$, issuing shares sold to existing or new shareholders (Svitek, 2001), and issuing long-term debt known as subordinated debt (Kleff \& Weber, 2008). Bank's profit can be calculated assuming $r$ and i are constant as follows:

$$
\begin{aligned}
& \pi=(1-T)\left(r^{*} L-i^{*} D\right) \\
& T=\operatorname{tax} \\
& L=\text { loan } \\
& D=\text { deposit } \\
& r=\text { rate of loan } \\
& i=\text { rate of deposit }
\end{aligned}
$$

If $\mathrm{L}=(1-\alpha)^{*} \mathrm{D}+\mathrm{E}$, where $\alpha$ is the reserve requirement of the central bank (Jiang, 2010). The two equations can be rewritten as follows:

$$
\begin{aligned}
& \pi=(1-\mathrm{T}) *\left[\mathrm{r} *\left\{(1-\alpha)^{*} \mathrm{D}+\mathrm{E}\right\}-\mathrm{i} * \mathrm{D}\right] \\
& \pi=(1-\mathrm{T}) *\left[\mathrm{r} * \mathrm{E}+\left\{(1-\alpha)^{*}(\mathrm{r}-\mathrm{i})\right\} * \mathrm{D}\right] \\
& \frac{\pi}{E}=(1-\mathrm{T}) *\left[\mathrm{r}+\left\{(1-\alpha)^{*}(\mathrm{r}-\mathrm{i})\right\} * \frac{D}{E}\right] \\
& \frac{\pi}{E} \text { is Return on Equity (ROE). If the equation (4) is created to be } \frac{\pi}{A}, \text { it is known }
\end{aligned}
$$

as Return on Asset (ROA). Equation (3) can be written back as follows:

$$
\frac{\pi}{A}=(1-\mathrm{T}) *\left[\mathrm{r} * \frac{E}{A}+\{(1-\alpha) *(\mathrm{r}-\mathrm{i})\} * \frac{D}{A}\right]
$$

Return on Equity and Return on Asset are the first indicator to see bank financial performance for practitioners, academics, and regulators (Manurung et al., 2021). For bank managers and regulators, risk refers to uncertainty of results and the negative consequences that may occur to the company, and aims to improve the bank's resilience in adverse situations. Financial risk is defined as the randomness of the return on investment, the greater expected return is associated with greater variability of results. In the financial industry, risk is determined by uncertainties that have adverse consequences on income or wealth, or uncertainties associated with negative outcomes only (Bessis, 2015).

Bank Risk can be measured by Value at Risk and Standard Deviation. Valueat-risk $(\mathrm{VaR})$ is the number of potential losses over a certain time period. Value at Risk requires the distribution of random asset values modeling over time. These random values are measured by price level variations or variations relative to the initial value, or returns. For market risk, variable $\mathrm{X}$ is the gain or loss of an asset or portfolio, the left side measures L's loss, as a variation in negative values. Value at Risk is the expected worst loss, L $\alpha$. For normal distribution, quantiles for different levels of trust are known as multiples of standard deviation. As the picture provided below, it 
appears that distribution is commonly used because it is only determined by two parameters, such as average and standard deviation, or volatility. For example, the deviation on the left side is greater than 2.33 (standard deviation) with a confidence level of $1 \%$, it occurs two to three days in a year, with 250 trading days (Bessis, 2015).

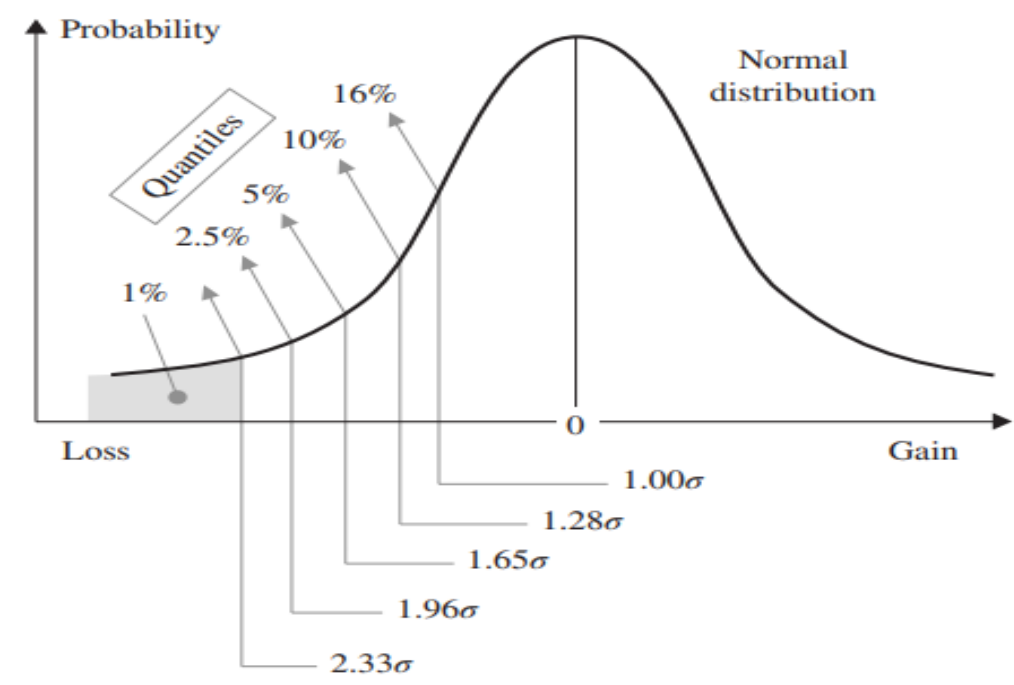

Figure 1. Normal distribution and one-tailed confidence levels (Bessis 2015)

\section{Modelling Random Shocks}

Random shocks can be defined as specific values of unpredictable components: $\mathrm{z \sigma} \sqrt{\mathrm{t}}$. Random Shocks is the occurrence of normal variables with standard deviations given per unit of time and $\mathrm{z}$ shocks are normal standards, with mean of 0 and standard deviation of 1 . After the shock, the new value of the asset becomes:

$\mathrm{Vt}=\mathrm{Vo} \exp (\mathrm{z} \sigma \sqrt{\mathrm{t}})$

The variation is: $\mathrm{Vt}-\mathrm{Vo}_{\mathrm{o}}=\mathrm{Vo}_{\mathrm{o}}[\exp (\mathrm{z} \sigma \sqrt{t})-1]$

With the same shock, the equivalent expressions in terms of discrete returns are:

$$
\begin{aligned}
& \mathrm{Vt}=\mathrm{Vo}(1+\mathrm{z} \sigma \sqrt{t}) \text { and } \mathrm{Vt}-\mathrm{Vo}_{\mathrm{o}}=\mathrm{Vo}_{\mathrm{o}} \mathrm{z} \sigma \sqrt{t} \\
& \mathrm{Vo} \quad=\text { Initial value of the asset } \\
& \mathrm{Vt} \quad=\text { New value of the asset } \\
& \mathrm{Z \sigma} \sqrt{t}=\text { Random Shocks }
\end{aligned}
$$

Based on VaR calculations from the picture above, it appears that the greater error is, the smaller VaR is. The looser the error is, the less risk to be tolerated.

\section{Time Variations}

Manurung (2017) states in calculating risk, it is often influenced by time variations. The data is often obtained annually and there is a daily demand into the future. Meaning that it is necessary to change the calculation of volatility from annually to daily. The mathematical formula is presented below, where the time period is divided into 2 terms, namely $\mathrm{t}$ and $\mathrm{t}-2$ period, so that the expectation and variance of both periods are explained as follows: 
$\mathrm{E}\left(x_{t}+x_{t-2}\right)=\mathrm{E}\left(x_{t}\right)+\mathrm{E}\left(x_{t-2}\right)=\mathrm{E}(\mathrm{x})+\mathrm{E}(\mathrm{x})=2^{*} \mathrm{E}(\mathrm{x})$

$\operatorname{Var}\left(x_{t}+x_{t-2}\right)=\operatorname{VaR}\left(x_{t}\right)+\operatorname{VaR}\left(x_{t-2}\right)+2 \operatorname{Covar}\left(x_{t}, x_{t-2}\right)$

$\operatorname{VaR}(\mathrm{x})+\operatorname{VaR}(\mathrm{x})=2^{*} \operatorname{VaR}(\mathrm{x})$

The formulation of time changing is presented below:

$\sigma^{2}=\sigma_{\text {annually }}{ }^{*} \mathrm{~T}$

$\mathrm{T}=$ Period $/ 252$

$\sigma=\sqrt{\frac{\sum\left\{R_{j, t}-E\left(R_{j}\right)\right\}^{2}}{n}}$

Where:

$\sigma=$ Standard deviation (Risk)

$R_{j, t}=$ Rate of return of assets in period $\mathrm{t}$

$R_{j, t}=\frac{\text { Div }+P_{E}-P_{B}}{P_{B}}$

Div $=$ Dividend

$P_{E}=$ Ending Price

$P_{B}=$ Beginning Price

$E\left(R_{j}\right)=$ Average rate of return over the period $\mathrm{n}$

$\mathrm{n}=$ Time period

$\mathrm{n}=$ as the number of periods in calculating standard deviation is often used $\mathrm{n}$ -1 , since the usable data is not always the whole data, but rather sampling data

$\sigma^{2}=$ Variance

\section{RESEARCH DESIGN}

The unit of research analysis are conventional banks listed on Indonesia Stock Exchange, Malaysia Stock Exchange, Philippine Stock Exchange, and Thailand Stock Exchange. Among 78 banks listed on those Stoch Exchanges of ASEAN-4 countries during the period of 2010-2019, there are only 35 banks that meet the research criteria. The modeling test was conducted against panel data regression to find out the influence of independent variables, such as Capital Adequacy Ratio, Non-Performing Loan, Loan To Deposit Ratio, Market Power, Exchange Rate, Interest Rate, and Technology Investment on dependent variables, such as Bank Risk proxied by Standard Deviation and Value at Risk with a moderating variable namely Bank Scale (BUKU Bank). The examination was conducted by dividing 35 banks into 2 examining groups. The first test was conducted on 35 banks in ASEAN-4 countries and the second one was conducted on 17 banks in Indonesia. ASEAN-4 countries are measured using dummy variables sorted by Gross Domestic Product in US\$ from the lowest to the highest value, with the GDP order namely Philippines, Malaysia, Thailand, and Indonesia.

\section{Modeling Test}

This study uses panel data regression to estimate the influence of independent variables, such as Capital Adequacy Ratio, Non-Performing Loan, Loan to Deposit 
Ratio, Market Power, Exchange Rate, Interest Rate, and Technology Investment on dependent variable, namely Bank Risk with proxies of Standard Deviation and Value at Risk, moderated by Bank Scale (BUKU Bank).

Estimated panel data model according to Gujarati (2011) as follows:

a. Pooled Data Model

$Y_{i t}=\beta_{1}+\beta_{2} X_{2 i t}+\beta_{3} X_{3 i t}+\mu_{i t}$

$i=1,2, \ldots . ., \mathrm{k} ; \mathrm{t}=1,2, \ldots \ldots, \mathrm{n}$

$i$ is a cross-section data that states the observation where the number is amounted as $k$, $t$ states the time with the amount of $n$.

b. Fixed Effect Model (FEM)

One of the techniques in inputting each company or cross-sectional unit is by creating the various intercepts for each company. Yet, it is still assumed that the slope coefficient is constant for each firm.

$Y_{i t}=\beta_{1 i}+\beta_{2} X_{2 i t}+\beta_{3} X_{3 i t}+\mu_{i t}$

$\mathrm{i}=1,2, \ldots . ., \mathrm{k} ; \mathrm{t}=1,2, \ldots . ., \mathrm{n}$

Subscript $\mathrm{i}$ on intercepts shows the intercepts of different companies, this difference is due to the managerial style or philosophy of each firm. $\beta_{1 i}$ means the intercepts vary against the company (i), but do not vary against time (t).

c. Random Effect Model (REM)

Greene (2012) stated the random effect model as follows:

$Y_{i t}=\left(\beta_{1}+\varepsilon_{i}\right)+\beta_{2} X_{2 i t}+\beta_{3} X_{3 i t}+\mu_{i t}$

$\mathrm{i}=1,2, \ldots . ., \mathrm{k} ; \mathrm{t}=1,2, \ldots . . \mathrm{n}$

From the equation above, the model intercept consists of a fixed coefficient $\left(\beta_{1}\right)$ added by $\varepsilon_{i}$ that states the error in each observation presents the characteristics of observation. The equation above can be rewritten as follows:

$Y_{i t}=\beta_{1}+\beta_{2} X_{2 i t}+\beta_{3} X_{3 i t}+\omega_{i t}$

Where, $\omega_{i t}=\varepsilon_{i}+\mu_{i t}$

$\omega_{i t}$ has two error components, namely cross-sectional error $\left(\varepsilon_{i}\right)$ and $\mu_{i t}$ which is a combined observation error and time-running periods.

\section{Methodology}

This study aims to examine the determinants of bank risk with the bank scale as the moderating variable on ASEAN banking. The research was conducted on conventional banks in the Indonesia Stock Exchange, Malaysia Stock Exchange, Phillipines Stock Exchange, and Thailand Stock Exchange during the period of 20102019. Based on the previous study, the research model is estimated below:

\section{Model 1}

$$
\begin{aligned}
\boldsymbol{S T D}_{i t} & =\alpha_{0}+\beta_{1} C A R_{i t}+\beta_{2} N P L_{i t}+\beta_{3} L D R_{i t}+\beta_{4} M P_{i t}+\beta_{5} E R_{i t}+\beta_{6} I R_{i t}+\beta_{7} T I_{i t} \\
& +\beta_{8} B B_{i t}+\beta_{9}\left(C A R_{i t}{ }^{*} B B_{i t}\right)+\beta_{10}\left(N P L_{i t}{ }^{*} B B_{i t}\right)+\beta_{11}\left(L D R_{i t}{ }^{*} B B_{i t}\right)+ \\
& \beta_{12}\left(M P_{i t}{ }^{*} B B_{i t}\right)+\beta_{13}\left(E R_{i t}{ }^{*} B B_{i t}\right)+\beta_{14}\left(I R_{i t}{ }^{*} B B_{i t}\right)+\beta_{15}\left(T I_{i t}{ }^{*} B B_{i t}\right) \\
& +\beta_{16} D_{1.1}+\beta_{17} D_{1.2}+\beta_{18} D_{1.3}+\varepsilon_{i t}
\end{aligned}
$$


Model 2

$$
\begin{aligned}
\boldsymbol{V a R}_{i t} & =\alpha_{0}+\beta_{1} C A R_{i t}+\beta_{2} N P L_{i t}+\beta_{3} L D R_{i t}+\beta_{4} M P_{i t}+\beta_{5} E R_{i t}+\beta_{6} I R_{i t}+\beta_{7} T I_{i t} \\
& +\beta_{8} B B_{i t}+\beta_{9}\left(C A R_{i t}^{*} B B_{i t}\right)+\beta_{10}\left(N P L_{i t}{ }^{*} B B_{i t}\right)+\beta_{11}\left(L D R_{i t}^{*} B B_{i t}\right)+ \\
& \beta_{12}\left(M P_{i t}{ }^{*} B B_{i t}\right)+\beta_{13}\left(E R_{i t}^{*} B B_{i t}\right)+\beta_{14}\left(I R_{i t}^{*} B B_{i t}\right)+\beta_{15}\left(T I_{i t}^{*} B B_{i t}\right) \\
& +\beta_{16} D_{1.1}+\beta_{17} D_{1.2}+\beta_{18} D_{1.3}+\varepsilon_{i t}
\end{aligned}
$$

\section{EMPIRICAL RESULTS}

\section{Descriptive Data}

This section will discuss the descriptive statistics of Bank Risk, Capital Adequacy Ratio, Non-Performing Loan, Loan to Deposit Ratio, Market Power, Exchange Rate, Interest Rate, Technology Investment, and BUKU Bank which are seen from the average value and variability of each variable. The following descriptive data

\begin{tabular}{|c|c|c|c|c|c|c|c|c|c|c|c|c|c|}
\hline Variabel & Mean & Median & Maximum & Minimum & Std. Dev. & Skewness & Kurtosis & Jarque-Bera & Probability & Sum & Sum Sq. Dev. & Observation & Cross sections \\
\hline VAR & 57.40158 & 22.79136 & 567.2163 & 0.084113 & 86.49907 & 2.995127 & 13.58844 & 2158.308 & 0 & 20090.55 & 2611249 & 350 & 35 \\
\hline NPL & 0.026943 & 0.022425 & 0.572 & 0.002144 & 0.033024 & 13.00459 & 213.4622 & 655824.2 & 0 & 9.429929 & 0.380622 & 350 & 35 \\
\hline LDR & 0.849255 & 0.87334 & 1.435082 & 0.395423 & 0.149241 & -0.208052 & 3.991546 & 16.8628 & 0.000218 & 297.2392 & 7.773199 & 350 & 35 \\
\hline $\mathbf{I R}$ & 0.045505 & 0.0425 & 0.0775 & 0.0125 & 0.018528 & 0.225675 & 1.921217 & 19.94255 & 0.000047 & 15.9268 & 0.119804 & 350 & 35 \\
\hline TI & 0.126256 & 0.009371 & 2.42 & $1.38 \mathrm{E}-05$ & 0.365563 & 3.796843 & 18.37623 & 4288.848 & 0 & 44.18953 & 46.63911 & 350 & 35 \\
\hline $\mathrm{BB}$ & 3.314286 & 3 & 4 & 2 & 0.708986 & -0.533576 & 2.11451 & 28.04238 & 0.000001 & 1160 & 175.4286 & 350 & 35 \\
\hline CAR_BB & 0.584304 & 0.559996 & 6.6024 & 0.136 & 0.362684 & 13.12698 & 218.0141 & 684254.8 & 0 & 204.5064 & 45.90736 & 350 & 35 \\
\hline NPL_BB & 0.088513 & 0.07598 & 2.288 & 0.004288 & 0.127128 & 14.89174 & 257.5554 & 957913.9 & 0 & 30.97956 & 5.640354 & 350 & 35 \\
\hline IR_BB & 0.148165 & 0.13 & 0.31 & 0.0375 & 0.066044 & 0.740593 & 2.898601 & 32.1445 & 0 & 51.8576 & 1.52228 & 350 & 35 \\
\hline TI_BB & 0.399473 & 0.030174 & 7.26 & $5.03 \mathrm{E}-05$ & 1.124619 & 3.593664 & 16.64228 & 3467.473 & 0 & 139.8155 & 441.4043 & 350 & 35 \\
\hline Dummy 1 & 0.2 & 0 & 1 & 0 & 0.400573 & 1.5 & 3.25 & 132.1615 & 0 & 70 & 56 & 350 & 35 \\
\hline Dummy 2 & 0.114286 & 0 & 1 & 0 & 0.318613 & 2.424672 & 6.879032 & 562.3774 & 0 & 40 & 35.42857 & 350 & 35 \\
\hline Dummy 3 & 0.485714 & 0 & 1 & 0 & 0.500511 & 0.057166 & 1.003268 & 58.33349 & 0 & 170 & 87.42857 & 350 & 35 \\
\hline
\end{tabular}
of all variables is provided below:

Table 1. Descriptive Statistics of Indonesia, Malaysia, Philippines, \& Thailand (ASEAN-4)

Source: Researcher Data Processing Results 
Table 2. Descriptive Statistics of Indonesia

\begin{tabular}{|c|c|c|c|c|c|c|c|c|c|c|c|c|c|}
\hline Variabel & Mean & Median & Maximum & Minimum & Std. Dev. & Skewness & Kurtosis & Jarque-Bera & Probability & Sum & Sum Sq, Dev. & Observation & Cross sections \\
\hline STD & 0.027399 & 0.024088 & 0.123759 & 0.008261 & 0.016324 & 3.245382 & 17.07715 & 1702,098 & 0 & 4.657825 & 0.045033 & 170 & 17 \\
\hline VAR & 69.49467 & 20.75735 & 567.2163 & 0.084113 & 113.7121 & 2.346335 & 8.251731 & 351.3463 & 0 & 11814.09 & 2185247 & 170 & 17 \\
\hline CAR & 0.184795 & 0.179981 & 0.464873 & 0.099214 & 0.045634 & 1.54772 & 10.12098 & 427.0547 & 0 & 31.41516 & 0.351937 & 170 & 17 \\
\hline NPL & 0.024568 & 0.022267 & 0.07664 & 0.002144 & 0.014423 & 1.084869 & 4.603593 & 51.56153 & 0 & 4.1766 & 0.035157 & 170 & 17 \\
\hline LDR & 0.8525 & 0.87339 & 1.435082 & 0.395423 & 0.154709 & -0.022572 & 4.669918 & 19.76721 & 0.000051 & 144.925 & 4.044985 & 170 & 17 \\
\hline$M P$ & 0.057503 & 0.028922 & 0.227704 & 0.00098 & 0.070855 & 1.29222 & 3.303263 & 47.96336 & 0 & 9.775506 & 0.848447 & 170 & 17 \\
\hline ER & $8.50 E-05$ & $7.75 E-05$ & 0.000111 & $6.95 \mathrm{E}-05$ & $1.59 E-05$ & 0.751768 & 1.806695 & 26.09922 & 0.000002 & 0.014447 & $4.25 E-08$ & 170 & 17 \\
\hline $\mathbb{R}$ & 0.061 & 0.06 & 0.0775 & 0.0425 & 0.01161 & -0.007978 & 1.761814 & 10.8613 & 0.00438 & 10.37 & 02278 & 170 & 17 \\
\hline $\mathrm{TI}$ & 0.01228 & 0.006269 & 0.085599 & $2.52 \mathrm{E}-05$ & 0.015537 & 2.327788 & 9.760949 & 477.3092 & 0 & 2.087559 & 0.040798 & 170 & 17 \\
\hline$B B$ & 3.117647 & 3 & 4 & 2 & 0.834348 & -0.222739 & 1.4795 & 17.78179 & 0.000138 & 530 & 117.6471 & 170 & 17 \\
\hline CAR BB & 0.574462 & 0.544256 & 1.394618 & 0.209412 & 0.202883 & 0.538882 & 3.258451 & 8.700965 & 0.012901 & 97.6586 & 6.956313 & 170 & 17 \\
\hline NPL_BB & 0.076284 & 0.070837 & 0.229921 & 0.004288 & 0.044932 & 0.589081 & 3.091157 & 9.890975 & 0.007115 & 12.96827 & 0.341196 & 170 & 17 \\
\hline LDR_BB & 2.674888 & 2.733699 & 4.304927 & 0.790846 & 0.876316 & -0.187105 & 1.930334 & 9.096552 & 0.010585 & 454.7309 & 129.7802 & 170 & 17 \\
\hline$M P_{-} B B$ & 0.221951 & 0.08923 & 0.910817 & 0.001961 & 0.287442 & 1.298878 & 3.283488 & 48.36999 & 0 & 37.73169 & 13.96323 & 170 & 17 \\
\hline ER_BB & 0.000265 & 0.000262 & 0.000444 & 0.000139 & $8.74 E-05$ & 0.448045 & 2.489826 & 7.531383 & 0.023152 & 0.045049 & $1.29 \mathrm{E}-06$ & 170 & 17 \\
\hline IR_BB & 0.190176 & 0.18 & 0.31 & 0.085 & 0.063196 & 0.292247 & 2.146779 & 7.57647 & 0.022636 & 32.33 & 0.674945 & 170 & 17 \\
\hline$T I B B$ & 0.035871 & 0.022258 & 0.18641 & $5.03 \mathrm{E}-05$ & 0.042705 & 1.82211 & 5.737618 & 147.1555 & 0 & 6.098081 & 0.308206 & 170 & 17 \\
\hline
\end{tabular}

Source: Researcher Data Processing Results

The results of descriptive statistical analysis in the table above can be interpreted as follows:

Risk with proxy Standard Deviation (STD) in banks in ASEAN-4 shows an average value of 0.020753 with a standard deviation value of 0.013654 , while the STD in banks in Indonesia shows an average value of 0.027399 with a standard deviation value of 0.016324 . When viewed the amount of risk to banks in ASEAN-4 countries has an average of almost the same as banks in Indonesia relatively small with low risk variability. So it can be concluded that bank risk in ASEAN-4 countries is relatively small.

Risk with proxy Value at Risk (VaR), in banks in ASEAN-4 countries showed an average value at 57.40158 with a standard deviation of 86.49907 . Value at Risk in banks in Indonesia has an average value of 69.49467 with a value of standard deviation of 113.7121 . This result shows that with the confidence level used $5 \%$ and the period in the year is 252 days, it can be said that there is a $5 \%$ chance that banks in ASEAN-4 will suffer a minimum loss of 57.40158 within the next 252 days, as well as for banks in Indonesia.

The Capital Adequacy Ratio (CAR) of banks in ASEAN-4 countries shows an average value of 0.176183 with a standard deviation of 0.087746 . In Bank Indonesia CAR has an average value of 0.184795 with standard deviation of 0.045634 . This result shows that CAR in ASEAN-4 countries and banks in Indonesia are already above CAR at least $8 \%$ with relatively small CAR variability. The growing Capital Adequacy Ratio will improve financial stability and the bank's ability to bear risks.

Non-Performing Loans (NPL) in banks in ASEAN-4 countries show an average value of 0.026943 with a standard deviation of 0.033024 . Non-Performing Loans in banks in Indonesia have an average value of 0.024568 with a value of standard 
deviation of 0.014423 . This result shows that Non-Performing Loans to banks in ASEAN-4 countries and Indonesia are relatively small, even the variability of NPL in banks in Indonesia is smaller than that of banks in ASEAN-4 countries.

The Loan to Deposits Ratio (LDR) of banks in ASEAN-4 countries shows an average value of 0.849255 with a standard deviation of 0.149241 . Loan to Deposits Ratio in banks in Indonesia has an average value of 0.852500 with a Standard Deviation value of 0.154709 . This result shows that banks in ASEAN-4 countries and Indonesia are very liquid because it is still at the maximum LDR limit of about $92 \%$, so that public deposits channeled into the form of loans still provide profitable income for banks.

Market Power (MP) in banks in ASEAN-4 countries shows an average value of 0.113644 with a standard deviation of 0.119037 . Market Power in banks in Indonesia has an average value of 0.057503 with a standard deviation of 0.070855 . Economic freedom caused MP to decrease and increase competition between banks, especially in banks in Indonesia.

Exchange Rate (ER) in banks in ASEAN-4 countries has an average value of 0.062778 with a value of standard deviation of 0.108015 . Exchange Rate at banks in Indonesia has an average value of 0.000085 with a standard deviation of 0.0000159 . This result shows that the exchange rate of Rupiah to US\$ is very low compared to other ASEAN countries currencies. Fluctuations in the exchange rate will be very influential especially for exporters and importers debtors, so it will affect the ability of borrowers in returning their loans.

Interest Rate (IR) in banks in ASEAN-4 countries has an average value of 0.045505 with a standard deviation of 0.018528 . Interest rate in banks in Indonesia has an average value of 0.061000 with a standard deviation of 0.01161 . This result shows that the average interest rate of banks in Indonesia is higher than other ASEAN countries. Because the interest rate is more regulated by the regulator so the variability is relatively small.

Technology Investment (TI) in banks in ASEAN-4 countries showed an average value of 0.126256 with a standard deviation of 0.365563 . Technology Investment in banks in Indonesia has an average value of 0.012280 with a value of standard deviation of 0.015537 . This result shows that technology investment in banks in ASEAN-4 countries is still very low, especially in banks in Indonesia and it is still very small, so banks in ASEAN-4 countries, especially Indonesia should increase investment in IT.

Moderating variables in the study are Bank Scale (BUKU Bank). The bank scale in banks in ASEAN-4 countries has an average value of 3.314286 with a standard deviation of 0.708986 . The bank scale in banks in Indonesia has an average value of 3.117647 , with a value of standard deviation of 0.834348 . From the table it appears that the larger the scale of the bank the capital adequacy ratio will be greater, because the big banks will be more trusted by investors in placing their funds, and some of the capital will be reserved on productive assets. While non-performing loans are not very significant with the scale of the bank, but the ratio of credit given to total deposits still 
provides income that can cover the costs of depositors, banks are quite able to manage the credit provided, so that the non-performing loans are quite low. The larger the scale of the bank, the market power will also increase, especially in banks in ASEAN4 countries such as in Thailand, but the number of banks in Indonesia causes competition sharp enough that market forces are not dominantly controlled by a bank or several banks only. Exchange rates and interest rates because they are macroeconomic variables are more regulated by regulators. The larger the scale of banks in ASEAN-4 countries, the investment in technology is also increasing from an average of 0.126256 to 0.399473 , but at banks in Indonesia the scale of the bank has little effect on the increase in technology investment.

\section{Result and Discussion}

Panel data regression can be analyzed using three models, namely common effect, fixed effect, and random effect models. Based on the data processing by EVIEWS 10.0, the appropriate model is random effect model. The first test was conducted on bankings in ASEAN-4 countries with the following results:

Table 3. The Results of Panel Data Regression with Random Effect Model on STD ASEAN-4 (Indonesia, Malaysia, Philippines and Thailand)

\begin{tabular}{|c|c|c|c|c|}
\hline Variable & Coefficient & Std. Error & t-Statistic & Prob \\
\hline $\mathrm{C}$ & 0.050017 & 0.017273 & 2.895736 & 0.002 \\
\hline CAR & -0.101163 & 0.038009 & -2.661581 & 0.0041 \\
\hline NPL & 0.054702 & 0.176608 & 0.309736 & 0.3785 \\
\hline LDR & 0.015957 & 0.020488 & 0.778823 & 0.2183 \\
\hline MP & -0.17575 & 0.087878 & -1.999939 & 0.02315 \\
\hline ER & -0.07929 & 0.036412 & -2.177551 & 0.01505 \\
\hline IR & -0.354075 & 0.271424 & -1.304511 & $0.0965 *$ \\
\hline TI & -0.0256 & 0.01313 & -1.94973 & 0.02605 \\
\hline $\mathrm{BB}$ & -0.006586 & 0.004245 & -1.551352 & $0.0609 *$ \\
\hline CAR BB & 0.024296 & 0.009744 & 2.493418 & 0.00655 \\
\hline NPL BB & -0.009507 & 0.044129 & -0.215443 & 0.4148 \\
\hline LDR BB & -0.008186 & 0.005266 & -1.554276 & $0.06055 *$ \\
\hline MP_BB & 0.041227 & 0.021935 & 1.879491 & 0.03055 \\
\hline ER BB & 0.013785 & 0.008208 & 1.67954 & 0.047 \\
\hline IR BB & 0.123165 & 0.07818 & 1.575416 & $0.05805 *$ \\
\hline TI_BB & 0.008414 & 0.004195 & 2.005944 & 0.02285 \\
\hline D 1 & 0.005848 & 0.003027 & 1.931601 & 0.02715 \\
\hline $\mathrm{D} 2$ & 0.011113 & 0.003076 & 3.613139 & 0.00015 \\
\hline D3 & 0.009472 & 0.00371 & 2.553107 & 0.00555 \\
\hline \multicolumn{3}{|l|}{$\mathbf{R}$-squ ared } & \multicolumn{2}{|l|}{0.13894} \\
\hline \multicolumn{3}{|l|}{ Adjusted R-Squared } & \multicolumn{2}{|l|}{0.092115} \\
\hline \multicolumn{3}{|l|}{ F-statistic } & \multicolumn{2}{|l|}{2.967225} \\
\hline \multicolumn{3}{|l|}{$\operatorname{Prob}(F$-statistic $)$} & \multicolumn{2}{|l|}{0.000059} \\
\hline
\end{tabular}

Significance at the $5 \%$ level, *Significance at the $10 \%$ level

Source: Researcher Data Processing Results

The result on Table 3 shows that CAR, MP, ER, IR, TI, and BB have significant negative effect on Bank Risk with proxy of STD, while NPL and LDR have no effect on STD. CAR_BB, MP_BB, ER_BB, IR_BB, and TI_BB have significant positive effect on STD. LDR_BB has significant negative effect on STD, while NPL_BB has no effect on STD. Bank Risk proxied by STD in Malaysia is smaller than in Indonesia, Thailand, and the Philippines. It can be seen from the coefficient of 0.005848 with the probability of $0.02715<\alpha 0.05$. It is statistically concluded that there is a significant difference of Bank Risk between Malaysia with Indonesia, Thailand, Philippines. 
Table 4. The Results of Panel Data Regression with Random Effects Model on VaR ASEAN-4 (Indonesia, Malaysia, Philippines, and Thailand)

\begin{tabular}{|c|c|c|c|c|}
\hline Variable & Coefficient & Std. Error & t-Statistic & Prob. \\
\hline C & -81.8993 & 68.79354 & -1.19051 & 0.11735 \\
\hline CAR & 78.18674 & 77.19586 & 1.012836 & 0.15595 \\
\hline NPL & 190.7474 & 227.9201 & 0.836905 & 0.20165 \\
\hline LDR & -148.307 & 50.04121 & -2.9637 & 0.00165 \\
\hline MP & 1035.6 & 574.9332 & 1.801254 & 0.0363 \\
\hline ER & 412.4987 & 381.0537 & 1.082521 & 0.1399 \\
\hline IR & -121.611 & 991.7767 & -0.12262 & 0.45125 \\
\hline TI & 142.1052 & 108.666 & 1.307724 & $0.09595 *$ \\
\hline $\mathrm{BB}$ & 8.858312 & 25.13716 & 0.352399 & 0.3624 \\
\hline CAR BB & -19.616 & 22.20516 & -0.8834 & 0.18885 \\
\hline NPL BB & -47.9229 & 58.01369 & -0.82606 & 0.2047 \\
\hline LDR BB & 61.7151 & 21.72082 & 2.841288 & 0.0024 \\
\hline MP BB & -185.496 & 116.759 & -1.58871 & 0.05655 \\
\hline ER BB & -83.0843 & 100.2474 & -0.82879 & 0.2039 \\
\hline IR BB & -79.0854 & 391.5972 & -0.20196 & 0.42005 \\
\hline TI BB & -44.9592 & 34.88313 & -1.28885 & $0.09915 *$ \\
\hline D 1 & -12.6596 & 25.44233 & -0.49758 & 0.30955 \\
\hline D2 & -72.0137 & 35.18996 & -2.04643 & 0.02075 \\
\hline D3 & 84.85121 & 29.41608 & 2.884518 & 0.0021 \\
\hline R-squared & & & \multicolumn{2}{|l|}{0.172987} \\
\hline Adjusted R-squared & & & \multicolumn{2}{|l|}{0.128014} \\
\hline F-statistic & & & \multicolumn{2}{|l|}{3.846426} \\
\hline Prob(F-statistic) & & & \multicolumn{2}{|l|}{0.00000} \\
\hline
\end{tabular}

Significance at the $5 \%$ level, *Significance at the $10 \%$ level

Source: Researcher Data Processing Results

The results in Table 4 show that LDR has significant negative effect on Bank Risk with the proxy of VaR. MP and TI have significant positive effect on VaR, while CAR, NPL, ER, IR, and BB have no effect on VaR. LDR_BB has significant positive effect on VaR, MP_BB and TI_BB have significant negative effect on VaR, while CAR_BB, NPL_BB, ER_BB, and IR_BB have no effect on VaR. Bank Risk proxied by $\mathrm{VaR}$ in Thailand is smaller than in Indonesia, Malaysia, and Philippines. It can be seen from the coefficient of -72.0137 with the probability of $0.02075<\alpha 0.05$. It can statistically be concluded that there is a significant difference of Bank Risk between Thailand with Indonesia, Malaysia, Philippines.

The research of bankings in ASEAN-4 countries shows that capital adequacy ratio, market strength, exchange rate, interest rate, technology investment, and bank scale will decrease the bank risk (STD). The average capital adequacy ratio of bankings in ASEAN-4 countries has exceeded the minimum limit of $8 \%$, regulated by BASEL II. This capital equity will minimize the liquidity risk and banks will have sufficient capital reserves for their productive assets. Large market strength makes some banks in the ASEAN-4 region dominant, such as in Thailand, TMB Bank controls the banking market by up to $65.30 \%$, so that these dominant banks are capable to minimize the risk. The limited number of banks in Malaysia, Philippines, and Thailand compared to Indonesia has caused the country's banking market to be more controlled by a group of banks. Exchange rate fluctuation and interest rate greatly affect the bank risk. The strengthening US\$ against the currency of ASEAN-4 countries will affect the debtors of exporters and importers. If banks distribute more loans to the debtors of exporters, it will lower the bank risk. The increasing interest rate will raise the amount of funds deposited by depositors so that banks will have 
fund resources large enough to be invested in productive assets that will result in greater interest income than interest expense. Banks need to increase investment in technology to increase their income, because people are more interested in placing their funds in banks that offer a variety of conveniences in DB usage. Start-up companies engaged in Fin-tech currently have a market that is millennials which is a potential market for banking, so banks must increase investment in technology if the market does not want to be taken by Start-up Fin-tech. Based on the research conducted, the larger bank scale is, the less bank risk it will take, but at the time the independent variable moderated by the bank scale some variables give results as opposed to direct influence.

The examination conducted against bank risk proximate by $\mathrm{VaR}$ yield different results with STD, as these two proxies use different measurements. The results of the test against the $\mathrm{VaR}$ model show that the greater the credit given to depositors will lower the risk of banks, because the average ratio of loans to 3rd party funds is still within the upper limit range of LDR which is about $92 \%$. Increasing market strength, the risk of banks will increase, because to become dominant in the market the bank will take advantage of high-risk investment opportunities in the hope of generating a large rate of return and to master the market the bank seeks to increase investment in the field of technology that requires large costs that are not balanced with the rate of return obtained. While at a time when independent variables are moderated by the scale of banks, the increase in credit given to depositors will increase risk, because a large source of funds will be channeled to larger loans, so the risk of bad loans will also be greater. Market forces and large technology investments will lower bank risk.

Some of the results of this study support previous research, such as research conducted by Ebenezer et al., (2019) at 63 commercial banks in ASEAN-5 countries during the period 2009-2017, using the regression of panel data, found that the Loan to Deposit Ratio (LDR) negatively affected bank risk. Rehman et al., (2018) stated that a more concentrated banking market will decrease competition and the same time will provide better access to bank deposits and loans, thus lowering risk. Jabra, Mighri and Mansouri (2017) conducted research in Eastern Europe and Western Europe, using panel data from 280 banks during the period 2005 to 2015, finding that excessive volatility in international financial markets, internal and macroeconomic factors can have a positive and negative effect on bank risk. Subramaniam, Rahim \& Selvarajan (2019) in their research in ASEAN from 2011- 2016 using Data Envelopment Analysis (DEA) found that development in the financial sector to increase market forces caused banks to spend a lot of money, thus becoming inefficient and increasing risk.

The second test was conducted against banks in Indonesia with the following results: 
Table 5. The Results of Panel Data Regression with Random Effects Model on STD Indonesian

\begin{tabular}{|c|c|c|c|c|}
\hline Variable & Coefficient & Std. Error & t-Statistic & Prob \\
\hline C & -0.00161 & 0.054009 & -0.02976 & 0.48815 \\
\hline CAR & 0.003996 & 0.122785 & 0.032544 & 0.48705 \\
\hline NPL & 0.175884 & 0.301696 & 0.582984 & 0.2804 \\
\hline LDR & 0.024055 & 0.03712 & 0.648028 & 0.25895 \\
\hline MP & -0.04311 & 1.12656 & -0.03826 & 0.48475 \\
\hline ER & 550.4932 & 341.5856 & 1.611582 & $0.05455 *$ \\
\hline IR & -0.51116 & 0.262488 & -1.94738 & 0.02665 \\
\hline TI & -0.71366 & 0.255335 & -2.79501 & 0.00295 \\
\hline BB & 0.004952 & 0.018361 & 0.269718 & 0.39385 \\
\hline CAR BB & -0.01089 & 0.047142 & -0.23103 & 0.4088 \\
\hline NPL_BB & 0.015983 & 0.104195 & 0.1534 & 0.43915 \\
\hline LDR_BB & -0.00881 & 0.01189 & -0.74087 & 0.22995 \\
\hline MP BB & -0.0016 & 0.282515 & -0.00565 & 0.49775 \\
\hline ER_BB & -104.316 & 108.7147 & -0.95954 & 0.1694 \\
\hline IR BB & 0.170068 & 0.072441 & 2.347694 & 0.0101 \\
\hline TI_BB & 0.220126 & 0.091383 & 2.40883 & 0.0086 \\
\hline \multicolumn{3}{|l|}{ R-squared } & \multicolumn{2}{|l|}{0.132992} \\
\hline \multicolumn{3}{|l|}{ Adjusted R-squared } & \multicolumn{2}{|l|}{0.048543} \\
\hline \multirow{2}{*}{\multicolumn{3}{|c|}{ F-statistic }} & \multirow{2}{*}{\multicolumn{2}{|c|}{$\frac{1.574822}{0.086607}$}} \\
\hline Prob(F-statistic) & & & & \\
\hline
\end{tabular}

Significance at the $5 \%$ level, *Significance at the $10 \%$ level

Source: Researcher Data Processing Results

The test results in table 5 show that ER has a significant positive effect on Bank Risk with proxy of STD, IR and TI have a significant negative impact on STDs. CAR, NPL, LDR, MP and BB have no effect on STD. IR_BB and TI_BB have a significant positive effect on STD, while CAR_BB, NPL_BB, LDR_BB, MP_BB and ER_BB, have no effect on STD.

Table 6. The Results of Panel Data Regression with Random Effects Model on VaR Indonesian

\begin{tabular}{|l|r|r|r|r|}
\hline \multicolumn{1}{|c|}{ Variable } & Coefficient & \multicolumn{1}{c|}{ Std. Error } & \multicolumn{1}{c|}{ t-Statistic } & \multicolumn{1}{c|}{ Prob } \\
\hline C & 88.07365 & 206.1642 & 0.427201 & 0.3349 \\
\hline CAR & -650.378 & 539.9565 & -1.2045 & 0.1151 \\
\hline NPL & 2952.513 & 735.249 & 4.015664 & 0.00005 \\
\hline LDR & -84.2084 & 39.93836 & -2.108459 & 0.0183 \\
\hline MP & 60.99964 & 3339.724 & 0.018265 & 0.49275 \\
\hline ER & 508824.4 & 699215.8 & 0.727707 & 0.23395 \\
\hline IR & 590.9968 & 1310.897 & 0.450834 & 0.32635 \\
\hline TI & -2576.5 & 686.8629 & -3.751104 & 0.0001 \\
\hline BB & -35.6434 & 92.75859 & -0.38426 & 0.35065 \\
\hline CAR_BB & 272.6649 & 226.2529 & 1.205133 & 0.115 \\
\hline NPL_BB & -1254.12 & 318.3721 & -3.939152 & 0.00005 \\
\hline LDR_BB & 42.19649 & 19.34785 & 2.180939 & 0.01535 \\
\hline MP_BB & 324.0799 & 752.2957 & 0.430788 & 0.3336 \\
\hline ER_BB BB & -223368 & 309641.6 & -0.721376 & 0.2359 \\
\hline IR_BB & -353.977 & 564.1065 & -0.6275 & 0.26565 \\
\hline TI_BB & 1158.647 & 359.8255 & 3.220024 & 0.0008 \\
\hline R-squared & & 0.278419 \\
\hline Adjusted R-squared & & 0.208135 \\
\hline F-statistic & & 3.961344 \\
\hline Prob(F-statistic) & & & 0.000005 \\
\hline
\end{tabular}

Significance at the $5 \%$ level

Source: Researcher Data Processing Results

The test results in table 6 show that NPL has a significant positive effect on Bank Risk with proxy of $\mathrm{VaR}, \mathrm{LDR}$ and IT have a significant negative effect on $\mathrm{VaR}$, while CAR, MP, ER, IR and BB have no effect on VaR. LDR_BB and TI_BB have a significant positive effect on VaR, NPL_BB has a significant negative influence on VaR. CAR_BB, MP_BB, ER_BB and IR_BB, had no effect on VaR. 
Based on research conducted on banks in Indonesia shows that increasing the exchange rate will increase the risk of banks being projected by STD. Fluctuations in the exchange rate will be strongly felt by imported debtors because they have to convert a growing amount of Rupiah to pay their debts in US\$. Increased interest rates and investments in technology will lower the risk. Investment in technology in Indonesian banking is still very low at around $1.23 \%$, so Indonesian banks need to improve digital transformation to be more competitive.

Tests conducted on bank risk projected by VaR show that a larger ratio of nonperforming loans will increase the bank's risk, the increase in credit given to depositors will increase non-performing loans, because disbursing depositors to high-risk productive assets without proper analysis will increase risk. The scale of banks in research conducted in Indonesia has no effect on risk, because the low market concentration due to the large number of banks in Indonesia will increase competition, this causes banks with scales 3 and 4 do not become dominant in the market.

Some of the research conducted at banks in Indonesia supports previous research. Fajar \& Umanto (2017), in its research on 20 banks listed on the Indonesia Stock Exchange (IDX) between Q1 2005 to Q4 2014, revealed that the previous NPL period and the ratio of Operating Expenses to Operational Costs (BOPO) had a significant positive influence on bank risk. Menicucci \& Paolucci (2016) in their European research during the period 2009-2013 using regression data panel found that LDR negatively influenced bank risk. Avdjiev, Bruno, Koch \& Shin (2019) in his US research stated that the Exchange Rate positively affects Bank Risk. His research found that a stronger U.S. dollar is associated with lower growth in cross-border interbank fund flows and lower real investment in emerging markets, thus hampering bank growth and increasing risk.

\section{E. CONCLUSION}

The research aims to test the risk determinants of banks moderated by the scale of banks in ASEAN. Random Effects Model is the best model for estimating panel data models. Testing was conducted on Bank Risk with Standard Deviation and Value at Risk proxy on banks in ASEAN-4 countries (Indonesia, Malaysia, Philippines and Thailand) and banks in Indonesia.

Tests conducted on the data panel regression model on banks in ASEAN-4 countries and banks in Indonesia provide the following conclusions: Capital Adequacy Ratio in banks in ASEAN-4 countries negatively affects STD, while in Indonesia CAR has no effect on Bank Risk, NPL in banks in ASEAN-4 countries has no effect on Bank Risk, but in banks in Indonesia NPL has a positive effect on VaR. Loan to Deposit Ratio on banks in ASEAN-4 countries and banks in Indonesia negatively affects VaR. Market Power on banks in ASEAN-4 countries negatively affects STD and positively affects VaR, but in Banks in Indonesia MP has no effect on Bank Risk. Exchange Rate in banks in ASEAN-4 countries negatively affects STD, but banks in Indonesia have a positive effect on STD. Interest Rate at banks in ASEAN- 
4 countries and banks in Indonesia negatively affect STD. Technology Investment in banks in ASEAN-4 countries negatively affects STD, but has a positive effect on VaR. In banks in Indonesia TI negatively affects Bank Risk. Bank Scale or BUKU Bank (BB) in banks in ASEAN-4 countries negatively affects STD, but in Banks in Indonesia BB has no effect on Bank Risk.

\section{REFERENCES}

1. Ahamed, M. M, \& Mallick, S. K. (2019). Is financial inclusion good for bank stability? International evidence. Journal of Economic Behavior and Organization, 157, 403-427. https://doi.org/10.1016/j.jebo.2017.07.027

2. Amat, C., Michalski, T., \& Stoltz, G. (2018). Fundamentals and exchange rate forecastability with simple machine learning methods. Journal of International Money and Finance, 88, 1-24. https://doi.org/10.1016/j.jimonfin.2018.06.003

3. Ashraf, B. N., Zheng, C., Jiang, C., \& Qian, N. (2020). Capital regulation, deposit insurance and bank risk: International evidence from normal and crisis periods. Research in International Business and Finance, 52, 1-19. https://doi.org/10.1016/j.ribaf.2020.101188

4. Avdjiev, S., Bruno, V., Koch, C., \& Shin, HS (2019). The Dollar Exchange Rate as a Global Risk Factor: Evidence from Investment. IMF Economic Review, 67(1), 151173. https://doi.org/10.1057/s41308-019-00074-4

5. Banna, H., \& Alam, MR (2021). Impact of digital financial inclusion on ASEAN banking stability: implications for the post-Covid-19 era. Studies in Economics and Finance, 38(2), 504-523. https://doi.org/10.1108/SEF-09-2020-0388

6. Barguellil, A., Ben-Salha, O., \& Zmami, M. (2018). Exchange rate volatility and economic growth. Journal of Economic Integration, 33(2), 1302-1336. https://doi.org/10.11130/jei.2018.33.2.1302

7. Ben Jabra, W., Mighri, Z., \& Mansouri, F. (2017). Determinants of European bank risk during financial crisis. Cogent Economics and Finance, 5(1), 1-21. https://doi.org/10.1080/23322039.2017.1298420

8. Bessis, J. (2015). Risk Management in Banking. New Jersey: Wiley.

9. Chi, J. (2018). Asymmetric effects of exchange rate and income changes on maritime freight flows between Japan and the US. Transport Policy, 69, 158-69. https://doi.org/10.1016/j.tranpol.2018.05.019

10. Ebenezer, O. O., Islam, M. A., Yusoff, W. S., \& Rahman, S. (2019). The effects of liquidity risk and interest-rate risk on profitability and firm value among banks in ASEAN-5 countries. Journal of Reviews on Global Economics, 8, 337-349. https://doi.org/10.6000/1929-7092.2019.08.29

11. Engle, R. F. (2002). Dynamic Conditional Correlation: A Simple Class of Multivariate Generalized Autoregressive Conditional Heteroskedasticity Models. Journal of Business $\mathcal{E} \quad$ Economic Statistics, 20(3), 339. https://doi.org/1198/073500102288618487 
12. Engle, R. F., \& Ruan, T. (2019). Measuring the probability of a financial crisis. Proceedings of the National Academy of Sciences of the United States of America, 116(37), 18341-18346. https://doi.org/10.1073/pnas.1903879116

13. European Commission. (2014). Proposal for a regulation on structural measures improving the resilience of EU credit institutions, COM (2014) 043 final", available at: http://eur-lex.europa.eu/ legal-content/EN/ALL/?uri=CELEX:52014PC0043

14. Fajar, H., \& Umanto. (2017). The impact of macroeconomic and bank-specific factors toward non-performing loan: Evidence from Indonesian public banks. Banks and Bank Systems, 12(1), 67-74. https://doi.org/10.21511/bbs.12(1).2017.08

15. Ghosh, A. (2015). Banking-industry specific and regional economic determinants of non-performing loans: Evidence from US states. Journal of Financial Stability, 20, 93-104. https://doi.org/10.1016/j.jfs.2015.08.004

16. Gujarati, D. (2011). Econometrics by Example; Palgrave Macmillan.

17. Harkati, R., Alhabshi, S. M., \& Kassim, S. (2020). Influence of economic freedom and its subcomponents on risk-taking behavior: Evidence from dual banking system of Malaysia. Review of Behavioral Finance, 12(4), 335-356. https://doi.org/10.1108/RBF-09-2019-0119

18. Hunjra, A. I., Hanif, M., Mehmood, R., \& Nguyen, L. V. (2020). Diversification, corporate governance, regulation and bank risk-taking. Journal of Financial Reporting and Accounting, 19(1), 92-108. https://doi.org/10.1108/JFRA-03-2020-0071

19. Jacques, K., \& Nigro, P. (1997). Risk-based capital, portfolio risk, and bank capital: A simultaneous equations approach. Journal of Economics and Business, 49(6), 533547. https://doi.org/10.1016/s0148-6195(97)00038-6

20. Jehan, Z., \& Hamid, A. (2017). Exchange rate volatility and capital inflows: role of financial development. Portuguese Economic Journal, 16(3), 189-203. https://doi.org/10.1007/s10258-017-0136-y

21. Kleff, V., \& Weber, M. (2008); How do Bank Determine Capital? Empirical Evidence from Germany. Germain Economic Review, 9(3), 354-372.

22. Le, T. H. (2021). Systemic risk in ASEAN-6: a new empirical investigation. International Journal of Emerging Markets. https://doi.org/10.1108/IJOEM-05-20200567

23. Louzis, D. P., Vouldis, A. T., \& Metaxas, V. L. (2012). Macroeconomic and bankspecific determinants of non-performing loans in Greece: A comparative study of mortgage, business and consumer loan portfolios. Journal of Banking and Finance, 36(4), 1012-1027. https://doi.org/10.1016/j.jbankfin.2011.10.012

24. Mahmud, A. (2020). Bank-specific and Macroeconomic Determinants of Profitability: Evidence from Conventional Private Commercial Banks Listed on Dhaka Stock Exchange, 4750. https://doi.org/10.5281/zenodo.4048039

25. Manurung, A. H. (2017). Bank Financial Risk Management. Jakarta: Adler Manurung Press.

26. Manurung, A. H., Hutahayan, B., Deniswara, K., Kartika, T. R. (2020). Bank Business Performance: Financial Ratio and Market Price Behavior. Jakarta: Adler Manurung Press. 
27. Manurung A. H., Kartono, R., Tjahjana, D., Tjiptadi, D., \& Saputra, N. (2021). Manajemen: Teori dan Perkembangannya. Jakarta: Adler Manurung Press.

28. Menicucci, E., \& Paolucci, G. (2016). The determinants of bank profitability: empirical evidence from European banking sector. Journal of Financial Reporting and Accounting, 14(1), 86-115. https://doi.org/10.1108/jfra-05-2015-0060

29. Meuleman, E., \& Vander Vennet, R. (2020). Macroprudential policy and bank systemic risk. Journal of Financial Stability, 47, 100724. https://doi.org/10.1016/j.jfs.2020.100724

30. Narayan, P. K, Phan, D. H. B., \& Liu, G. (2021). COVID-19 lockdowns, stimulus packages, travel bans, and stock returns. Finance Research Letters, 38, 101732. https://doi.org/10.1016/j.frl.2020.101732

31. Nguyen, Q. T. T., Gan, C., \& Li, Z. (2019). Bank capital regulation: How do Asian banks respond? Pacific Basin Finance Journal, 57, 1-25. https://doi.org/10.1016/j.pacfin.2019.101196

32. Ozili, P. K. (2020). Non-performing loans in European systemic and non-systemic banks. Journal of Financial Economic Policy, 12(3), 409-424. https://doi.org/10.1108/JFEP-02-2019-0033

33. Phan, D. H. B., \& Narayan, P. K. (2020). Country Responses and the Reaction of the Stock Market to COVID-19-a Preliminary Exposition. Emerging Markets Finance and Trade, 56(10), 2138-2150. https://doi.org/10.1080/1540496X.2020.1784719

34. Rachman, R. A., Kadarusman, Y. B., Anggriono, K., \& Setiadi, R. (2018). Bankspecific factors affecting non-performing loans in developing countries: Case study of Indonesia. Journal of Asian Finance, Economics and Business. https://doi.org/10.13106/jafeb.2018.vol5.no2.35

35. Rehman, Z. U., Khan, S. A., Khan, A., \& Rahman, A. (2018). Internal Factors, External Factors, and Bank's Profitability. Sarhad Journal of Management Sciences, 4(2), 246-259.

36. Saheruddin, H., \& Soedarmono, W. (2019). Financial crisis and cointegration of systemic risk in Southeast Asian banking. Jurnal Keuangan dan Perbankan, 23(4), 479-488. https://doi.org/10.26905/jkdp.v23i4.3669

37. Subramaniam, V. P. R., Ab-Rahim, R., \& Selvarajan, S. K. (2019). Financial development, efficiency, and competition of ASEAN banking market. Asia-Pacific Social Science Review, 19(3), 185-202.

38. Svitek, I. M. (2001). Functions of Bank Capital. BIATEC, Rocnik, 9(5), 37-40.

39. Van Roy, P. (2008). Capital requirements and bank behavior in the early 1990: cross country evidence. International Journal of Central Banking, 4(3), 29-60.

40. Wilner, B. S. (2000). The exploitation of relationships in financial distress: The case of trade credit. The Journal of Finance, 55(1), 153-178. https://doi.org/10.1111/00221082.00203

41. Wójcik, D., \& Ioannou, S. (2020). COVID-19 and Finance: Market Developments So Far and Potential Impacts on the Financial Sector and Centres. Tijdschrift Voor Economische En Sociale Geografie, 111(3), 387-400. https://doi.org/10.1111/tesg.12434 
42. Wu, F. (2019). Stock market integration in East and Southeast Asia: the role of global factors. International Review of Financial Analysis, 67, 101416. doi: 10.1016/j.jphotochem.2019.112061 